\title{
KETIDAKPATUHAN TKI : SEBUAH PROSES PENDAMPINGAN DI TENGAH HUKUM MODERN
}

\author{
Erwin Widhiandono, \\ Dosen Fakultas Hukum Universitas Islam Balitar, \\ E-mail: erwinwidhiandono@yaoo.co.id
}

\begin{abstract}
ABSTRAKSI
Ketidakpatuhan Tenaga Kerja Indonesia (TKI) ke Malaysia asal desa Sugihan lebih disebabkan karena mengikuti prosedur pemerintah dirasakan menyulitkan, karena banyak aturan; melalui prosedur pemerintah pemberangkatannya terlalu lama; pemerintah seringkali tidak jujur; serta tidak memiliki kebebasan untuk memilih pekerjaan.
\end{abstract}

Kata kunci : Ketidakpatuhan, birokrasi

\section{PENDAHULUAN}

Sektor pekerjaan nonpertanian yang berasal dari ekonomi supradesa dalam wujud sebagai Tenaga Kerja Indonesia (TKI) ke luar negeri ini menarik untuk diteliti. Pertama, karena pekerjaan sektor nonpertanian dalam bentuk ekonomi supradesa ini mampu mengubah status sosial ekonomi petani. Penelitian Nasution mencatat, 1bahwa migran Indonesia mampu meningkatkan taraf hidup keluarganya dari pendapatan yang mereka peroleh selama bekerja di Malaysia. $65 \%$ migran berhasil dalam memenuhi kebutuhan makan telah naik dari kurang memuaskan, dan sangat kurang memuaskan 23,0 \% sebelum bekerja di Malaysia ke tingkat memuaskan (86,3 \%) dan sangat memuaskan (5,7 \%). TKI ke Malaysia asal desa Sugihan, Kecamatan Solokuro, Kabupaten Lamongan, Jawa Timur yang menjadi objek penelitian ini juga menunjukkan perbaikan ekonomi. Sebanyak 80 \% mereka mampu membeli tanah, ternak, emas dan perabotan rumah tangga lainnya serta membangun desanya, organisasi sosial keagamaannya.

Banyak diantara mereka menjadi orang-orang kaya baru di desanya. Keadaan demikian tentunya jauh lebih baik dibandingkan ketika mereka masih menjadi buruh tani di pedesaan. Kedua, mampu menambah devisa negara. TKI asal Jawa Timur misalnya, yang bekerja di luar negeri selama tahun 2001 menghasilkan devisa sebesar Rp. 1,3 trilyun, dengan total TKI legal asal Jawa Timur berjumlah 160. 000 orang. Belum lagi yang ilegal. Hanya saja untuk menjadi TKI tersebut terdapat persyaratan-persyaratan dan prosedur sebagaimana diatur melalui Kepmenakertrans Nomor Kep- 104 A/MEN/2002 dan kemudian diperbarui dengan Undang Undang Nomor 39 Tahun 2004 yang diberlakukan sejak Januari 2005. Dalam situasi seperti itu, calon-calon TKI ke Malaysia asal desa Sugihan tidak mengikuti persyaratan-persyaratan dan prosedur sebagaimana yang telah ditentukan. Prosedur demikian masyarakat desa Sugihan menyebutnya, melalui jalan gelap, atau secara populer orang menyebutnya secara ilegal.

\footnotetext{
${ }^{1}$ Periksa M.Arif Nasution, Orang Indonesia di Malaysia, Yogyakarta : Pustaka Pelajar, 2001. Hal. 118
} 
Berdasarkan temuan penelitian sebelumnya, ${ }^{2}$ memperlihatkan bahwa pembangunan pertanian di desa seringkali membawa dampak yang akhirnya mendorong penduduk desa berimigrasi, terutama buruh tani. Pembangunan sektor pertanian telah mengurangi peluang buruh tani untuk bekerja sebagai petani bagi hasil selama musim panen. Sistim "tebasan" yang mengontrakkan penuaian kepada orang luar menjadi luas berlaku di Jawa. Begitu pula penggunaan buruh wanita dalam penumbukan padi (Jawa : nutu) telah berkurang, karena telah digantikan mesin-mesin. Lebih dari 30 \% penduduk pedesaan pulau Jawa sangat bergantung pada pekerjaan sebagai buruh tani. Merekalah yang kini kehilangan kesempatan pekerjaan karena adanya sistim tebasan baru tersebut. Saat ini, bahkan bukan hanya sistim tebasan saja yang mempengaruhi peluang pekerjaan mereka, tetapi dampak penggantian "ani-ani" dengan "sabit" turut pula mempersempit peluang tersebut. Dari uraian tersebut, dapat disimpulkan bahwa sistim tebasan telah membatasi jumlah orang terlibat dalam pekerjaan penuaian. Seterusnya pembatasan jumlah buruh pemotong padi ini lebih diperburuk lagi dengan adanya sistim tebasan menggunakan orang yang sama pada setiap musim panen. Ini berarti makin mengurangi lagi jumlah buruh tani terlibat dalam sektor pertanian tersebut. Melalui penelitian sebelumnya memperlihatkan pula berkurangnya peluang kerja di pedesaan akibat penggunaan teknologi pertanian. Misalnya sebuah traktor dapat menggantikan 2210 hari masa kerja buruh setiap tahun.

Penemuan di atas, menunjukkan bahwa usaha pemerintah untuk memodernisasi pertanian tidak hanya mengakibatkan berkurangnya peluang pekerjaan para buruh tani, justru keadaan itu telah melahirkan proses pemiskinan yang berkesinambungan. Dengan kondisi demikian, kemungkinan untuk melakukan migrasi internasional mereka anggap sebagai satu pilihan paling baik. Lebih-lebih pemerintah telah memberikan contoh kebijakan beberapa negara Asia dalam mengirimkan tenaga kerjanya ke berbagai negara seperti Thailand, Pakistan, India, Srilangka, Bangladesh, Filipina. ${ }^{3}$ Namun persoalannya, untuk menjadi buruh migran (TKI) ke luar negeri ini memerlukan prosedur, dan aturan-aturan yang proses pengurusannya pun terlalu sukar bagi calon buruh migran tersebut, karena harus melalui proses birokrasi yang sukar dijangkau oleh masyarakat desa yang rata-rata berpendidikan rendah. Lebih-lebih jika harus menjadi buruh migran ke negara-negara Timur Tengah. Akhirnya mereka lebih memilih menjadi buruh migran (TKI) ke Malaysia, karena faktor kesamaan budaya serta jarak yang relatif dekat. Sekalipun demikian banyak diantara mereka masuk ke Malaysia tanpa proses keimigrasian yang sah.

Persoalan yang kemudian muncul, ketika para buruh migran (TKI) memasuki Malaysia itu tanpa melalui proses yang legal sebagaimana diatur melalui Keputusan Menteri Tenaga Kerja Dan Transmigrasi Republik Indonesia Nomor Kep - 104 A/MEN/2002 tentang Penempatan Tenaga Kerja Indonesia Ke Luar Negeri, yang telah diperbarui melalui Undang Undang Nomor

\footnotetext{
2 Periksa William Collier, Sistem Tebasan, Bibit Unggul dan Pembaharuan Desa di Jawa, , Jakarta: Prisma 1974. Hal.10

3 Periksa Hugo, Population Mobility in West Java, Yogyakarta: Gadjah Mada University Press, 1978.Hal.13
} 
39 Tahun 2004, maka TKI - TKI tersebut akan mengalami sejumlah perilaku yang cenderung mengeksploitasi mereka, baik ketika mereka masih berada di kampung halaman sampai dengan mereka dideportasi dari negara tujuan. Hal itu terlihat ditemukannya sindikat penculikan Tenaga Kerja Indonesia (TKI) yang berhasil dibongkar petugas Polwil Surakarta. Para korban penculikan adalah para TKI yang baru pulang dari Malaysia dan kemudian dijemput oleh komplotan tertentu di pelabuhan Belawan, Medan. Belum lagi beberapa persoalan lain yang dialami para TKI ini, misalnya, gaji yang seluruhnya atau sebagian belum terbayar, besar gaji yang tidak sesuai dengan yang diperjanjikan, sampai dengan menjadikan para Tenaga Kerja Wanita (TKW) untuk pelacuran. Sekretaris Eksekutif Konsorsium Pembela Buruh Migran Indonesia (KOPBUMI) menuturkan, kasus yang menimpa buruh migran sepanjang tahun 2000, antara lain 33 orang meninggal, ditipu 1820 orang, diterlantarkan 34707 orang. Kehilangan kontak 24.325 orang, tidak memiliki dokumen 1.563 .334 orang, dokumen dipalsukan 32.390 orang, dipenjara 14.222 orang, dideportasi 137.866 orang, diadili di Mahkamah Syariah 50 orang, ditangkap saat razia 6.427 orang $^{4}$ Data demikian tentunya lebih kecil dari situasi yang sebenarnya, karena masih banyak kasus-kasus yang tidak dilaporkan atau sengaja disembunyikan. Apalagi jumlah ini belum termasuk korban perdagangan perempuan (trafficking in woman). Ditambah lagi kerusuhan beberapa waktu lalu yang dilakukan oleh sejumlah TKI di Malaysia yang menjadikan berangnya pemerintah Malaysia.

\section{METODE PENELITIAN}

Berdasarkan kenyataan di atas, melalui penelitian lapangan (field research), penelitian ini bertujuan untuk mendeskripsikan hal-hal yang menjadi alasan TKI ke Malaysia yang tidak memiliki keterampilan tidak menggunakan prosedur Kepmenakertrans Nomor Kep- 104 A/MEN/2002.

Metode pendekatan yang dipergunakan dalam penelitian ini adalah pendekatan nondoktrinal ( socio legal research) 5 Penelitian dengan menggunakan pendekatan socio legal research berangkat dari sebuah konsep, bahwa hukum tidak hanya dilihat sebagai aturan-aturan normatif belaka, tetapi juga dilihat sebagai bagian dari proses dalam kehidupan masyarakat. Karena itu hukum dan konteks sosial dimana hukum itu berada perlu diteliti secara bersamaan. ${ }^{6}$

Penelitian ini dilakukan di desa Sugihan, Kecamatan Solokuro, Kabupaten Lamongan, Jawa Timur. Desa penelitian dipilih secara purposive. Penelitian ini menggunakan data kualitatif dengan alasan bahwa dinamika ekonomi pertanian yang menjadikan keterdesakan ekonomi buruh tani yang kemudian menjadi pendorong untuk melakukan migrasi menjadi Tenaga Kerja Indonesia (TKI) ke Malaysia serta proses-proses pemberangkatannya, mulai dari alasan mereka memilih menjadi buruh migran, yang mendorong mereka menjadi buruh migran, mereka memilih bos, serta faktor-faktor yang mendorong mereka tidak menggunakan prosedur atau

4 Kompas, 23 Januari 2003

5 Periksa Soetandyo W, Hukum dan Metode-Metode Kajiannya, tanpa tahun.

${ }^{6}$ Periksa Moore, Law as Process : An Anthropological Approach, Rondledge \& Kegan Paul, London, 1983.Hal.55. 
aturan tentang penempatan Tenaga Kerja Indonesia (TKI) ke luar negeri dapat digali lebih mendalam.

Analisis dilakukan dengan menafsirkan data yang diperoleh secara induktif dan membandingkan dengan teori yang sudah ada. Pembandingan ini dimaksudkan untuk mengkaitkan temuan tersebut dengan teori yang mengkaji hal yang menjadi fokus kajian. ${ }^{7}$ Berdasarkan penafsiran secara induktif tersebut dikemukakan konsep-konsep yang berkaitan dengan tindakan yang dilakukan oleh responden terhadap aturan tentang penempatan kerja ke luar negeri. Konsep-konsep tersebut kemudian diabstraksikan dalam pemikiran teoritik yang berdasarkan data. Dengan demikian pengembangan teoritik yang dilakukan dalam penelitian ini berdasar pada data ${ }^{8}$.

\section{SUMBER-SUMBER NAFKAH PETANI}

Penelitian ini memberi gambaran, bahwa sumber-sumber pokok pendapatan petani asal desa Sugihan sebelum masuknya sektor ekonomi nonpertanian yang berasal dari ekonomi supradesa (TKI) tersebut, terdapat pada tanah sawah dan tanah tegalan. Sebelum masuknya ekonomi supradesa (TKI) yang termasuk kategori petani kaya (Jawa : uwong sugih) di desa Sugihan menurut sumber Kepala Desa Sugihan, hanya sejumlah 7 orang. Selebihnya tergolong petani menengah dan sebagain besar buruh tani (Jawa : uwong ora duwe).

Apabila dilihat dari pola pengolahan tanah sawah atau tegalan, maka yang pertama kali memperoleh pekerjaan di dalam proses pengolahan sawah itu adalah buruh tani laki-laki dan sebagian petani menengah. Sedangkan bagi buruh tani wanita, pekerjaan itu baru diperoleh ketika musim tanam, baik untuk menanam tanaman sawah maupun tegalan.

Beberapa jenis pekerjaan buruh tani, hasil yang diperoleh hanyalah sebatas untuk memenuhi kebutuhan hidup sehari-hari. Bahkan tidak jarang buruh tani yang menetap bekerja pada keluarga petani kaya tertentu, upah yang mereka peroleh hanyalah berbentuk makan dan upah lainnya atas keikhlasan petani kaya.

Sebelum masuknya penggunaan bibit padi unggul, dengan waktu pertumbuhan yang relatif pendek, sistim pertanaman yang berlaku di desa Sugihan adalah satu kali tanam padi, yang memerlukan waktu panen 1 tahun sekali.

Sejalan dengan modernisasi pertanian di pedesaan, maka pada tahun 1984 untuk pertama kalinya di desa Sugihan bibit padi jenis unggul mulai diperkenalkan dengan jenis PB-5 atau IR5. Jenis padi unggul ini cepat meluas penggunaannya melalui keterlibatan birokrasi pemerintahan desa, dan dibarengi dengan penggunaan pupuk kimia, pestisida dan insektisida. Akibat pola tanam padi demikian, petani desa Sugihan menanam padi 2 kali setahun berturutturut. Perubahan pola tanam, kemudian diikuti pola perubahan memanen hasil pertanian, terutama memanen padi. Dari serangkaian perubahan itu yang terasa menjadikan perubahan adalah, pola memanen tanaman padi. Waktu itu memanen padi (Jawa : derep) buruh tani

7 Periksa S.A. Schlegel, Realitas dan Penelitian Sosial, Badan Pembinaan Hukum Nasional Departemen Kehakiman, Jakarta, 1982.Hal.69.

8 Periksa S.A. Schlegel, Penelitian Grounded dalam Ilmu-Ilmu Sosial, Fakultas Ilmu-Ilmu Sosial, Fakultas Ilmu Sosial Politik, Surakarta :Universitas Sebelas Maret, 1984. Hal.14. 
wanita desa Sugihan dapat terlibat secara keseluruhan, dengan menggunakan, "ani-ani" (pisau pemotong padi), kemudian berubah memanen padi dilakukan oleh buruh tani laki-laki dengan menggunakan,"sabit". Dengan pola lama, apabila seorang buruh wanita menghasilkan 6 ikat (Jawa : agem) maka upahnya (Jawa : bawon) nya 1 ikat.

Perubahan lebih lanjut dari pola memanen tanaman padi yang dilakukan oleh buruh tani laki-laki itu, adalah munculnya mesing giling padi (huller) oleh petani kaya tertentu. Dampak yang lebih terasa adalah hilangnya sumber-sumber pendapatan bagi buruh tani wanita, yaitu menumbuk padi (Jawa : nutu). Dengan demikian, maka buruh tani wanita telah kehilangan dua macam pekerjaan. Yang lebih beruntung, justru petani kaya, karena perubahan pola tanam dan pola memanen itu menjadikan pola-pola itu lebih efisien dari sisi biaya maupun waktu. Kemana sesungguhnya pergeseran pekerjaan buruh tani wanita akibat keterdesakan tersebut. Mereka sesungguhnya tidak memiliki ruang gerak yang cukup, melainkan tetap terpasung pada sisa-sisa sumber-sumber pendapatan tradisionalnya.

\section{MUNCULNYA SEKTOR EKONOMI NONPERTANIAN}

Di tengah suasana ekonomi pertanian sebagaimana tergambar di atas, pada tahun 1985 munculah informasi tentang peluang untuk menjadi Tenaga Kerja Indonesia (TKI) ke Malaysia sebagai kuli bangunan dengan menjanjikan upah sebesar Rp. 130. 000,- per hari. Tentu saja upah sebesar itu jauh di atas upah seorang buruh tani, bahkan petani kaya sekalipun.

Pada awalnya buruh tani desa Sugihan dalam menerima informasi itu sebagian besar termasuk kelompok lambat (late majority). Hal demikian masih sejalan dengan persepsi manusia Jawa terhadap wilayah, mobilitas, dan lingkungan budaya yang membentuknya. Persepsi manusia Jawa tentang wilayah berkaitan erat dengan persepsi tentang tanah, karena keterikatan masyarakat Jawa dengan tanah kelahiran (sedentary) memang teramat kuat. Keterikatan itu menjadi kendala budaya yang menyebabkan masyarakat Jawa kurang berminat meninggalkan tanah asalnya, jika memang tidak amat terpaksa. Sehingga dapat dimengerti, jika tanggapan masyarakat Jawa terhadap faktor mobilitas setidaknya pasif atau reaktif, kalaupun tidak dinilai negatif. ${ }^{9}$ Namun kemudian setelah 10 (sepuluh) bulan mereka yang telah menjadi TKI itu telah menunjukkan keberhasilannya, yakni mampu mengirim uang kepada keluarganya untuk mengganti biaya pemberangkatan ke Malaysia maupun untuk kepentingan keluarganya, maka tidak terbendunglah keinginan untuk menjadi TKI bagi buruh tani desa Sugihan. Sejumlah 80 (delapan puluh) orang mendaftarkan diri untuk menjai TKI ke Malaysia. Hal demikian membuktikan bahwa melalui informasi-informasi baru itu kemudian memunculkan perasaan, bahwa yang baru lebih baik dari apa yang sudah ada. ${ }^{10}$ Dengan demikian, maka toleransi terhadap penyimpangan norma masyarakatnya, yakni ketika itu masih kuatnya falsafah Jawa" mangan ora mangan sing penting kumpul", ( makan ataukah tidak

9 Periksa Rofiq Ahmad (Ed), Budaya Kepeloporan Dalam Mobilitas Penduduk, Kerjasama Puspaswara dengan Departemen Transmigrasi dan PPH, Jakarta, 1997.Hal.158-159.

10 Periksa Horwitz, Three World of Development, The Theory of International Stratification, Oxford University Press, 1972. Hal.491. 
bisa makan yang penting kumpul) dapat ditunjuk sebagai salah satu tahap kemajuan sebuah masyarakat.

Sebanyak 770 buruh tani asal desa Sugihan sedang menjadi TKI ke Malaysia. Dari sejumlah itu $80 \%$ telah menjadi orang kaya baru di desa Sugihan. Mereka memiliki kemampuan mengirim uang tiap tahunnya antara Rp. 24. 000. 000,- sampai dengan Rp. 50. 000. 000,- jauh lebih besar apabila dibandingkan dengan penghasilan seorang petani kaya desa Sugihan.

Melihat realitas keberhasilan TKI di atas, memberikan gambaran bahwa distribusi penguasaan atas sumber tanah yang lebih merata akan meningkatkan standar kehidupan orang yang miskin ${ }^{11}$ ada kelemahannya, apabila sumber tanahnya terbatas, demikian pula kualitasnya. Yang lebih mendekati kenyataan, adalah bahwa menurunnya penguasaan atas tanah dan landless belum tentu berarti kemiskinan di pedesaan, apabila tersedia pekerjaan lain di sektor nonpertanian dalam skala yang cukup besar.

\section{TENAGA KERJA INDONESIA KE MALAYSIA ASAL DESA SUGIHAN}

Tenaga Kerja Indonesia (TKI) asal desa Sugihan sebagian besar bekerja pada sektor konstruksi sebagai pekerja kasar (kuli bangunan). Pekerjaan mereka tidak memerlukan keterampilan khusus maupun pendidikan khusus. Sedangkan Keputusan Menteri Tenaga Kerja Dan Transmigrasi Nomor Kep-104 A/MEN/2002 maupun Undang Undang Nomor 39 Tahun 2004 mensyaratkan keterampilan atau keahlian dan tingkat pendidikan tertentu, yaitu serendah-rendahnya SLTP atau sederajat. Bekerja pada sektor konstruksi atau bangunan ini mereka pilih, oleh karena sekurang-kurangnya ada 3 alasan, yakni pertama : sektor konstruksi atau bangunan ini pendapatannya relatif tinggi dari pada sektor lainnya. Kedua : bekerja di sektor konstruksi atau bangunan ini lebih memudahkan pindah kerja dari tempat yang satu ke tempat yang lain. Hal ini berbeda dengan TKI sebagaimana yang diprogramkan pemerintah selama ini, mereka dikontrakkan. Ketiga : ada kerja lembur dengan memperoleh tambahan gaji yang lebih tinggi, yakni sebesar 10 Ringgit per jam.

Migran biasanya mempunyai alasan-alasan tertentu yang menyebabkan mereka meninggalkan kampung halamannya dan seterusnya memilih tempat-tempat yang mereka anggap dapat memenuhi keinginan yang kurang atau tidak dapat terpenuhi kalau sekiranya tetap bertahan di tempat asal.12 Sebagian besar (97\%) TKI asal desa Sugihan beralasan bahwa mereka memilih menjadi TKI, karena bekerja sebagai TKI akan memperoleh gaji besar. Alasan demikian lebih didorong mengingat ekonomi keluarga sangat tergantung pada kearifan sumber-sumber nafkah tradisional (sawah maupun tegal). Selebihnya memberi jawaban ingin memperoleh pengalaman (1\%); mudah mencari uang $(1 \%)$; serta ingin hidup mandiri $(1 \%)$. Alasan terakhir ini tentunya tidak terlepas dengan kebiasaan masa lalu, ketika ekonomi supradesa dalam wujud sebagai TKI ini belum masuk ke pedesaan. Ketika itu ekonomi anak

\footnotetext{
11 Periksa Joan Hardjono, Tanah, Kerajaan dan Nafkah, Yogyakarta: Gadjah Mada University Press, 1987.Hal.174-180.

12 Periksa M.Arif Nasution, 2001.Op.Cit. Hal.35.
} 
menjadi beban tanggungan orang tua dalam bentuk pemberian harta yang berupa sawah atau tegal. Sehingga akan terlihat dengan pasti peta kekuatan ekonomi seorang anak. Jika saja ia dilahirkan dari keluarga kaya, maka sekurang-kurangnya mereka akan menjadi keluarga kaya, karena memiliki sumber-sumber pencarian nafkah dalam bentuk sawah dan tegal yang cukup, melalui proses pewarisan.

Atas dorongan siapa sesungguhnya buruh tani asal desa Sugihan ini ke luar dari lingkungan sosial dan geografisnya, ketika sumber-sumber nafkah tradisionalnya tidak lagi cukup menjanjikan kesejahteraan kehidupan keluarga mereka. Sebagian besar (72\%) TKI memberi jawaban, bahwa mereka bekerja ke Malaysia atas kemauan sendiri. Hal ini memperlihatkan, bahwa sesungguhnya motivasi untuk berimigrasi itu berasal dari migran itu sendiri. Selebihnya (28 \%) TKI memberi jawaban atas dorongan teman. Dengan demikian, maka teman sesungguhnya juga memiliki peran strategis dalam membentuk motivasi calon-calon TKI. Sementara itu istri tidak memiliki peran yang signifikan dalam membentuk motivasi suami. Hal demikian, masih sejalan dengan ekonomi petani, bahwa nafkah itu adalah tanggungjawab suami, sekalipun dalam kesehariannya istri juga memiliki peran yang cukup besar dalam pencarian nafkah. Bahkan tidak satu pun atas dorongan orang tua.

Dilihat dari proses pemberangkatan ke Malaysia, sejak awal pemberangkatan TKI asal desa Sugihan yakni tahun 1985, dan bahkan hingga kini selalu bersama broker (98\%). Masyarakat Sugihan menyebutnya, "bos". Hanya sebagian kecil (2\%) TKI tidak menggunakan jasa bos, karena mereka telah memiliki pengalaman berangkat ke Malaysia. Alasan mereka memperlihatkan, bahwa memilih bos itu lebih memudahkan untuk mencarikan pekerjaan (87 \%). Jaminan bahwa bos akan mencarikan pekerjaan, teramat penting bagi calon TKI. Oleh karena dengan jaminan cepat memperoleh pekerjaan, calon TKI segera memiliki kepastian mengembalikan biaya untuk keperluan proses pemberangkatan ke Malaysia tersebut. Oleh karena tidak sedikit biaya untuk proses pemberangkatan itu sifatnya pinjaman. Serta untuk memberikan kiriman keluarga. Selebihnya ( 60 \%) TKI memberi jawaban karena resiko ditanggung bos. Jawaban demikian, mengingat bahwa prosedur yang mereka pilih itu adalah prosedur di luar aturan pemerintah yang penuh resiko selama perjalanan, bahkan sampai dengan negara tujuan. Maka jaminan resiko ditanggung oleh bos itu terasa amat penting. $17 \%$ bersama bos memudahkan pengurusan pemberangkatan. Hal demikian mengingat calon-calon TKI ini rata-rata berpendidikan rendah serta sehari-harinya hanya berkutat dilingkungan sumber-sumber nafkah tradisonalnya, yang tidak terbiasa dengan urusan kepentingan birokrasi pedesaan, apalagi kecamatan bahkan Kantor Imigrasi Surabaya. Bersama bos itu mereka dipinjami biaya untuk proses pemberangkatan (1\%); mereka merasa terlindung (1\%); bisa pilih pekerjaan (1\%). Beban bos sebagaimana yang dijanjikannya itu menjadi berkurang, jika saja calon-calon TKI memliki famili atau teman akrab yang tengah bekerja di Malaysia. Oleh karena famili atau teman akrab itu akan berperan mencarikan pekerjaan, memberikan perlindungan ketika calon-calon TKI itu masih dalam status tak berdokumen. Hal demikian masih sejalan dengan salah satu karakteristik masyarakat pedesaan, bahwa pergaulannya ditandai oleh 
derajad intimitas yang tinggi antara sesama anggota masyarakat dan bahkan antar kerabat. ${ }^{13}$ Temuan ini memperlihatkan, berapa pun murahnya harga sebuah hukum, tetapi jika saja mengikuti prosedur hukum itu dirasakan menyulitkan, seseorang itu lebih memilih prosedur di luar ketentuan yang ada melalui jasa orang lain sekalipun harus membayar mahal.

Mengacu pada kesimpulan simposium nasional dengan tema Kesadaran Hukum Masyarakat dalam Masa Transisi yang dilaksanakan oleh Badan Pembinaan Hukum Nasional (BPHN) di Jakarta Tahun 1975, bahwa salah satu unsur dalam proses agar orang sadar terhadap hukum adalah adanya pengetahuan terhadap hukum yang bersangkutan. Kata "sadar" mengandung pengertian "tahu dan memahami". Dengan demikian mengetahui dan memahami suatu hukum merupakan unsur penting dalam proses pentaatan hukum tersebut. Kesadaran hukum merupakan hasil dari serangkaian proses hubungan yang saling berkaitan antara ketiga unsur, ${ }^{14}$ yaitu (1) pengetahuan terhadap hukum, (2) penghayatan/pemahaman fungsi hukum, dan (3) ketaatan terhadap hukum.

TKI asal desa Sugihan tidak memilih prosedur menjadi TKI sebagaimana diatur melalui Keputusan Menteri Tenaga Kerja Dan Transmigrasi Republik Indonesia Nomor Kep - 104 A/MEN/ 2002 maupun Undang Undang Nomor 39 Tahun 2004. Pertama: apabila dilihat dari sisi pengetahuan mereka terhadap aturan tentang penempatan Tenaga Kerja Indonesia (TKI) ke luar negeri memperlihatkan, bahwa sebagian besar (98\%) TKI mengetahui, bahwa untuk menjadi TKI itu terdapat aturan pemerintah. Meskipun demikian, TKI yang memberikan jawaban mengetahui, mereka tidak mengetahui isi peraturan itu secara rinci. Sebagian kecil TKI (2\%) memberikan jawaban tidak mengetahui. Pengetahuan tentang peraturan itu diperoleh dari bos $(91 \%)$ dan cerita teman-teman mereka yang sebelumnya pernah mengikuti prosedur dan aturan pemerintah (9\%). Kedua : pengetahuan demikian melahirkan pemahaman bahwa sebagian besar (50 \%) TKI asal desa Sugihan memahami bahwa mengikuti prosedur pemerintah itu dirasakan terlalu sulit, karena banyak aturan. Jawaban itu cukup beralasan, lihatlah misalnya Keputusan Menteri Tenaga Kerja Dan Transmigrasi menyebutkan, bahwa setiap calon TKI yang mendaftar harus telah mengikuti penyuluhan tentang syarat-syarat kerja, prosedur dan kelengkapan dokumen, situasi dan kondisi sosial budaya negara tujuan dan seterusnya. Bagi calon TKI yang akan mengikuti penyuluhan harus memenuhi beberapa syarat, misalnya batas minimal umur; berpendidikan sekurang-kurangnya tamat SLTP atau sederajat; memiliki ketrampilan atau keahlian; dibuktikan dengan sertifikat ketrampilan. Selebihnya TKI memberi jawaban proses pemberangkatannya lama (29\%). Hal demikian mengingat melalui prosedur resmi proses birokrasi cukup panjang, untuk ukuran seorang buruh tani. Mengikuti prosedur pemerintah tidak bisa bebas memilih pekerjaan (16\%). Mereka lebih suka berpindah-pindah tempat bekerja yang lebih menyenangkan dan menguntungkan, dari pada harus bekerja dengan sistim kontrak sebagaimana diprogramkan oleh pemerintah. Melalui pemerintah banyak makelar (4\%), oleh karena pemerintah tidak mau turun sendiri ke masyarakat.

13 Periksa Leibo, Strategi Pembangunan Masyarakat Desa, Andi Offset, Yogyakarta, 1995. Hal.22

14 Periksa Salman, Beberapa Aspek Sosiologi Hukum, PT. Alumni, Bandng, Cet. I. 2000. Hal. 67-69 
Pemerintah tidak jujur. Jawaban demikian oleh karena seringkali apa yang diperjanjikan umumnya tidak sesuai dengan keadaan. Misalnya jenis pekerjaan maupun gaji yang dijanjikan.

Temuan di atas memberikan gambaran dalam dimensi teoritis maupun praktis. Dalam dimensi teoritik, bahwa faktor kultur (Friedman) ${ }^{15}$, faktor nilai-nilai yang berlaku (Parsons) tidak terlihat dalam konteks tidak digunakannya Keputusan Menteri Tenaga Kerja Dan Transmigrasi Republik Indonesia Nomor Kep- 104 A/MEN/ 2002 tentang penempatan Tenaga Kerja Indonesia ke luar negeri. Yang terlihat adalah teori pertukaran (exchange theory) nya Homans ${ }^{16}$, yakni bahwa jika menjadi TKI itu mengikuti prosedur dan persyaratan-persyaratan sebagaimana tertuang di dalam Kepmenakertrans tersebut dirasakan merugikan dari sisi waktu maupun penghasilan. Pada tataran dimensi praktis, temuan ini memperlihatkan sebuah ketaatan pada hukum akan menjadi berkurang atau bahkan hilang sama sekali, jika saja dengan hukum orang menjadi sulit untuk memenuhi kebutuhannya. Melalui prosedur hukum memakan waktu yang lama, serta orang tidak bisa bebas untuk melakukan pilihan-pilihan. Jika hal itu terjadi, maka orang lebih memilih prosedur-prosedur yang dapat dimanipulasi.

Berdasarkan penelitian di atas, kaitannya dengan kebijakan negara dalam hal penempatan TKI ke luar negeri sejalan dengan otonomi daerah dimana soal pengaturan ketenagakerjaan menjadi wewenang pemerintah daerah, maka perlunya Peraturan Daerah (PERDA) tentang perlindungan TKI ke luar negeri, baik yang mensyaratkan keterampilan (skilled) maupun yang tidak mensyaratkan perlunya keterampilan (unskilled). Hal ini berdasarkan realitas bahwa bekerja yang tidak memerlukan keterampilan khusus pun terdapat di luar negeri, dan hal itu merupakan jaminan konstitusi. Mengingkari realitas tersebut hakekatnya sama dengan melanggar konstitusi.

15 Periksa Friedman, The Legal System : A Social Science Perspektive, Russel Sage Foundation, New York, 1977. Hal. 11-12

16 Periksa M. Poloma, Sosiologi Kontemporer, Rajawali Press, Jakarta, 1987. Hal. 262-264 


\section{DAFTAR PUSTAKA}

1978 "Law and Social Change : The Semi autonomous Social Field an Appropriate Subject of Study", dimuat kembali dalam Sally Fal Moore, Law As Process: An Anthropological Approack, Routledge \& Kegan, London.

Collier, William, Masalah pangan Pengganguran dan Gerakan Revolusi Hijau Di Pedesaan Jawa, Prisma. 1978.

Collier, William. L. et. Sistem Tebasan, Bibit Unggul dan Pembaharuan Desa di Jawa, Prima 3(6). LP3ES. 1974.

Friedmann, Lawrence M. The Legal System. A Social Science Perspective. Russel Sage Foundation, New York. 1975.

Hardjono, John. Tanah, Pekerjaan Dan Nafkah, Yogyakarta: Gadjah Mada University Press, 1987.

Hugo, G.J. Indonesian Labour Migration Migration to Malaysia : Trends and Policy Implication, Southeast Asian Journal of Social Science. 1993. . Population Mobility in West Java, Yogyakarta: Gadjah Mada Universitas Press, 1975.

Leibo. Strategi Pembangunan Masyarakat Desa Berparadigma Ganda, Yogyakarta : Andi Offset, 1995.

Moore, S.FLaw as Process : An Anthropological Approuch, Routledge E Kegan Paul, London. . 1983.

Nasution, M. Arif. 1996. Peroses Perjalanan Immigran Indonesia Ke Malaysia. Kertas Kerja Seminar Peranan Tenaga Kerja Asing Dalam Pembangunan. Kerja sama FISIP-USU dengan FSKKUKM, Medan, 27 Mei

Salman, O. R. Beberapa Aspek Sosiologi Hukum, Bandung: Alumni, 1989.

Schlegel, S.A Realitas Dan Penelitian Sosial, Badan Pembinaan Hukum Nasional Departemen. Jakarta : Kehakiman. 1982.

Wignjosoebroto, Soetandyo, Hukum Dan Metode-Metode Kajiannya, tanpa tahun 